\title{
THE IMPACT OF DOMESTIC GASTRONOMIC FESTIVALS ON THE LOCAL ACCOMODATIONS
}

\begin{abstract}
István BOTTYÁN ${ }^{\mathrm{a}}$
${ }^{a}$ University of Pécs, Faculty of Business and Economics, Regional Politics and Economics Doctoral School, Address: Fehérvári út 82., Budapest, Hungary, 1117, phone: +36-30-210-29-72, e-mail: istvan.bottyan@topartbudapest.hu
\end{abstract}

Cite this article: Bottyán, I. (2015). The Impact of Domestic Gastronomic Festivals on the Local Accomodations. Deturope, 7, 2: 188-205

\begin{abstract}
Food festivals are a mainstay of the festival sector and some surveys show that they currently account for 30 percent. Despite this, we know very little about this important part of event tourism, and its economic and social impacts. This study tries to show, by econometric methods, the impacts on the local economy made by food festivals - and, at the same time, fhe effects -of the multiplicator and spillover factors.

This paper looks for some correlation between the local index-number of tourism and gastronomic festivals, using data from more than 200 events and festivals and 123 settlements. The first step in the survey was to determine two tourism factors, and this was followed by our methodological studies of these factors.

Although the summarized conclusions may not support the general opinion as can be found in the relevant literature - that is, a positive correlation between gastronomic festivals and local tourism, new research directions are revealed.
\end{abstract}

Keywords: tourism, festival-tourism, gastronomy, hospitality, econometrics, descriptive statistics

\section{INTRODUCTION}

The main objective of this study is to give some insight into the world of domestic food festivals and to understand their social and economic impacts. I would like to emphasize the importance of these special events and their role in the tourism industry, both at regional and national level. My (nearly seventeen years) experience and my studies in the field of culinary tourism, supported my conviction that gastronomy can define the competitiveness of tourism in a region or country. Areas, regions with an adequate, clearly identifiable culinary character, together, of course, with quality, differentiate themselves very effectively from their competitors.

The culinary brand, or "unique offer ${ }^{61 "}$ formation, however, points much farther, because it generates results by statistical methods beyond the non-measureable soft ${ }^{62}$ factors.

\footnotetext{
${ }^{61}$ Unique offer or USP. A unique sales offer to the customer, which is only available at the given place or only the given provider or producer can make available
} 
The most effective way to present so-called 'local gastronomy' is by gastronomic festivals and events, sincel, for the duration of these events. the focus of the communication and all of the acts focusing on the culinarity, and the statements, made in this time, are relatively exact way to demonstrate the various economic and social impacts.

The main purpose of this study to give an objective picture of the world of domestic culinary events and festivals, of their role in the tourism industry, of their multiplier ${ }^{63}$ and spillover $^{64}$ effects on the economy. In this context my first and foremost task was to gather the Hungarian food festivals based on available databases, and to create a single database, which is representative, summarizes the domestic events, and contains information that may be suitable to explore the fundamental correlations related to gastronomic festivals. I aim to create a single, multi-year multi-panel database which is not only the foundation for my own research, but which can serve as a starting point for further work.

Today there is a lively international interest in understanding the impact of food and food and wine festivals on the region's economy, and on its development.

Several papers and surveys were undertaken which examined the phenomenon and the importance of the gastronomic festivals (Duarte and Yi, 2011; Erdős, 2004; Ottenbacher and Harrington, 2011; Lee and Arcodia, 2011; Lakićević and Žarevac and Pantić, 2010,). These works basically highlight the novelty of the festival, a kind of lack of substitutes role and impact on the region's economy and society.

However, in the past few years here were fundamentally changes in the role of gastronomy in tourism. The 'self-serving sector' role is replaced gradually by destination value and attraction; also the positive image and educational impact of gastronomic festivals which can influence the long-term life of a brand is generated by agriculture. When I started to create the database to compile my work I immediately faced the problem that, in many cases, there is no single concept of such festivals in the literature.

However there are many interpretation of the concept of festivals, eg Häusserman 1993. In: Kundi (2012), Harris and Howard (1996), Vrettos (2009), all of these authors agreeing more or less, that it is essential that there are marked boundaries to the "festival", preventing the

\footnotetext{
${ }^{62}$ In my paper and during my work I refer to factors as 'soft' if theyare not necessarily based on explicitly discernible facts, but rather on experiences and intuition.

63 'Touristic multiplier' means the relationship of how much total income a unit of spending in tourism generates in the economy. This is a spiralling effect with a final consequence of greater economic activity. The income multiplier can essentially be captured within direct spending by the salaries paid to employees and their spending, but there are other multipliers as well among which production stands out, which is the stimulating effect of a unit of spending in tourism to the rate of economic production." (Michalkó 2004: 209)

${ }^{64}$ Spillover is not a market transaction, so there is no contractual relationship between the sending and receiving entity; the phenomenon itself arises as an externality. (Meyer, 2004)
} 
devaluation of the word 'festival' (Kundi, 2012). This is all the more important, because data can be collected, and empirical studies can be conducted on this basis.

Currently, the most important objective was to make the largest possible number of samples, and so I used the wider interpretation of the concept - hence the 'multi-day' and 'regular' were not a concern. I consider it appropriate to analyse the "one-day" events as well - whether designation - because they have also culinary purposes, are also periodic events, and as additional program elements can impact on tourism of the region. Based on this interpretation i consider all festival or event as a ,gastronomic festival”, where the focus is on a kind of agricultural crop (eg. pumpkin, cherry, apple...), on a kind of food (eg. fish soup, aspic, dödölle - special potato dish...), on a kind of food product (eg. ham, sausage, chees, wein, palinka...), or on special traditional food producter craft (eg. pigsticker, baker...). In general, these groups are the main types of the gastronomic festival.

Summerizing all the information and datas in one definition, culinary festival can be considered every one or multy-day events, that is organized regularly time to time, its main objective of the local gastronomy and agricultutrial raw materials and crops presentation. It has four different types, depending on what in its main focus is.

\section{FESTIVALS BASED ON GASTRONOMY}

\section{Economic multiplier}

When examining the economic, multiplier and external effects related to festivals, it seemed sensible to review the effects of the whole, including tourism and the entire industry. What I read and experienced helped me a great deal in gaining a more accurate picture of the direct results and consequences of festivals.

However, all authors were in agreement that it is a "highly complex issue..." (Michalkó, 2012; Kundi, 2012; Bolgár, Saayman and Rossouw, 2010; Hunyadi et al., 2006; Puczkó, 1999), and cannot be measured simply on the basis of direct economic figures, approaching it from one direction (ticket income, multiplying the amount of money sent in by each person on average - established using questionnaire survey - with the number of visitors) (Saayman and Rossouw, 2010). Their impact, just as that of tourism, is much more complex, starting from the effect they have on the current balance of payments, GDP, rate of employment (Michalkó, 2012) and tax payments (Saayman and Rossouw, 2010) through socio-cultural externals 
(Kundi 2012) and effects on nature (Putzkó,1999) which all have values that can be defined indirectly in money terms ${ }^{65}$.

If you simply try to specify the direct costs of festivals, then you can easily draw the conclusion that the cost side is relatively easy to define; infrastructural conditions, performers, organisers, security, medical duty... - "As opposed to a cost side relatively easy to overview, translating income into numbers is, as you can see from the above list, is much more difficult." (Hunyadi et al., 2006), which approach however would show a quite one-sided picture, since it would not take into account the negative external effects paid by the community. If you translate both factors into numbers, and compare them with the direct economic results of festivals, i.e. ticket saled, then the conclusion is that "many festivals are loss-generating, and this is why such events need public funding..." (Smith, 2009; Hunyadi et al., 2006). A loss-generating operation however can often be traced back to great number of festival organisers who do not take into consideration other sources, e.g. rents, income from commerce, etc. (Hunyadi et al., 2006).

Kundi as well draws attention to the high costs and indirect returns of festivals by saying that "Festivals (and related events) cost a lot and are rarely organised to gain direct economic benefits from them. The majority of these festivals are loss-generating "at an operational level", thus require large amounts of typically "public funding". However, he immediately adds that "It is obvious however that festivals directly or indirectly contribute a lot to the stimulation of the economy in an extremely wide scale." (Hunyadi et al 2006, p. 27).

The biggest problem with measuring economic effects within the country is that $\mathrm{KSH}$ (Central Statistical Office) does not collect data regarding festivals, since this activity was not classified into TEÁOR 08 independently; thus the extent of the employment of organisers (which could be measured in each industry and for each activity) cannot be seen. (Kundi, 2012)

In parallel with the increase in the number and gravity of festivals, attempts to measure economic, multiplier and spillover effects also become more frequent:

- the role of the employment multiplier

- based on enjoyment economy66 (Kundi, 2012)

- Presenting positive and negative externals (Puczkó, 1999),

- Measuring socio-cultural effects (Kundi, 2006.).

\footnotetext{
${ }^{65}$ A good example of this is the payment obligation defined by the British economist Pigou, which is essentially an environmental tax serving as a counter-balance to negative social impacts of certain activities

${ }^{66}$ Enjoyment economy can be summed up in the following: In the place of an approach accumulating financial assets, a new enjoyment-centred philosophy of life has come into existence.
} 
In addition, Kundi mentions several other methods in his work: Small - Edwards Sheridan's "Retrospective Method (2005); Tourism Satellite Account System; Social Effect Assessment; Social Effect Analysis (referring to studies by Small and Edward and Sheridan, 2005); Touristic effect attitude scale (Kundi, 2012).

Besides direct and indirect economic benefit, the employment multiplier is mentioned most often by researchers, although, many of them also point out the seasonality (Michalkó, 2012, Hunyadi et al. 2006). However, they all agree that employment is the most important factor behind the section of economic and socio-cultural effects of festival tourism. "In tourism terms direct employment effect means the employees, who get into personal contact with visitors (hotels, airlines, restaurants, entertainment industry, etc.), while induced employment includes the employees, who do not have personal contact with visitors, but are indirectly connected to tourism (industrial providers, governmental bodies, producers of capital and export assets used also in tourism)" (Tourism Office 2004). There is another method for calculating job creation, which, in addition to employees employed directly or indirectly, calculates the "festival benefit" in jobs. Accordingly, how much the direct and indirect expenses of the festival increased the total annual employment figures of the region (Hunyadi et al., 2006).

In addition to the direct and indirect effects of festivals, other impacts must also be considered: improving popularity, creating jobs, educating and training local residents, infrastructural development, increase in investments... that is, positive and negative externals and spillovers.

\section{Spillover effects}

When the externals of festivals and gastronomic events are examined, it is practical to take into account the "spillover effects" arising in connection with tourism, then to assess them and re-interpret them, if necessary, in relation to festivals.

External, natural or built environmental, socio-cultural effects can be classified from various perspectives. They can be examined from that of their general effect, positive vs. negative, or their explicit measurability, can be measured in money terms (change in profit) or cannot be presented monetarily (change in the level of wellness) or their effect on society or the individual. These were compiled and systematised by numerous authors from various perspectives of interpretation by grouping (Mathieson and Wall (1982), Krippendorf (1987), Allen (1988), Crompton and Sanderson (1990), Urry (1991), Harrison (1992), McKercher (1993), Pearce (1989) et al.). In consideration of the ultimate goal of my study, I chose 
monetay measurability as the main perspective of categorisation by assessing its two values, positive or negative (Tab. 1).

Table 1 External effects

\begin{tabular}{|c|c|c|}
\hline & Can be translated into money & Cannot be translated into money \\
\hline Positive externals & $\begin{array}{l}\text { - At a lower and medium level the } \\
\text { development of tourism is } \\
\text { financial by nature } \\
\text { - Infrastructural improvements, } \\
\text { whose benefits are enjoyed by } \\
\text { the local population also. } \\
\text { - Increasing the popularity of the } \\
\text { region, consequently the } \\
\text { competitiveness of products of } \\
\text { the local small-scale industry } \\
\text { improves (e.g. Békéscsaba } \\
\text { sausage). } \\
\text { - Improvement in exports from } \\
\text { the region. } \\
\text { - Strengthening of local small- } \\
\text { scale industry. } \\
\text { Real estate prices rise as a result } \\
\text { of touristic investments. } \\
\text { Maintaining, restoring and } \\
\text { developing investments in the } \\
\text { built and natural environment. } \\
\text { - Increasing tax income. } \\
\text { - Stimulation of retail processes. }\end{array}$ & $\begin{array}{l}\text { - The flexibility of the touristic } \\
\text { employment structure erodes } \\
\text { gender segregation. } \\
\text { - There are more opportunities in } \\
\text { tourism for women, enabling their } \\
\text { economic independence. } \\
\text { - Tourism offers new opportunities } \\
\text { and examines social changes. } \\
\text { - It promotes more aware public } \\
\text { thinking in order to preserve our } \\
\text { values and environment. } \\
\text { - Declining migration. } \\
\text { - New recreational opportunities. } \\
\text { - Demand for a healthier life-style } \\
\text { and higher qualification. } \\
\text { - Residents knowledge of the } \\
\text { world improves. } \\
\text { - Understanding other cultures } \\
\text { helps in accepting them. }\end{array}$ \\
\hline
\end{tabular}


Table 1 (continued)

\begin{tabular}{|c|c|c|}
\hline Negative externals & $\begin{array}{l}\text { - Investments are rather profit- } \\
\text { oriented (swimming pool) than } \\
\text { cost-focused (sewage cleaning } \\
\text { plant) } \\
\text { - The rise in prices as a result of } \\
\text { higher touristic popularity. } \\
\text { - Erosion of the natural and built } \\
\text { environment, pollution of the } \\
\text { environment. } \\
\text { - More costly maintenance of } \\
\text { existing and over-sized } \\
\text { infrastructure. } \\
\text { - Decline in real estate value. } \\
\text { - Lack of goods. } \\
\text { - Decaying public services. } \\
\text { Increase in imports. }\end{array}$ & $\begin{array}{l}\text { - It changes the inner structure of } \\
\text { the community: those in } \\
\text { connection with tourism and the } \\
\text { ground getting in contact with } \\
\text { tourists and tourism. } \\
\text { - Tourism may have colonising } \\
\text { features depriving the local } \\
\text { population of the ability to make } \\
\text { decisions independently. } \\
\text { - Certain environmental effects, } \\
\text { such as noise and dust pollution, } \\
\text { damage to natural assets (flora and } \\
\text { fauna). } \\
\text { - Large numbers of foreign words } \\
\text { integrating into the language, } \\
\text { disappearance of old expressions. } \\
\text { - Increase in crime rates. } \\
\text { - Increase in the crowdedness of the } \\
\text { region, the recreation of the locals } \\
\text { becomes impossible. } \\
\text { - Antipathy towards peoples, } \\
\text { cultures or religious groups due to } \\
\text { strange customs. } \\
\text { The spread of global culture to the } \\
\text { detriment of local values. } \\
\text { Negative behavioural patterns for } \\
\text { the next generations }\end{array}$ \\
\hline
\end{tabular}

Source: The author's own construction

Among the externals shown in the table with relation to tourism in general, many can be observed or considered notable in case of numerous festivals. Out of effects that are positive and can be translated into money, perhaps the most accepted is the increase in tax income, improvement in brand popularity (Békéscsaba's sausage, Baja's fish soup, Miskolc's jellied pork ...), rise in real estate prices within the region and the strengthening of local small-scale industry (distillation of spirits, viticulture, production of cheese and other food...). Others that can be explicitly measured are the stimulation of retail business and the increase in the income of local shops.

However, among positive externals that can hardly be captured financially, it is obvious that festivals provide new opportunities for the local population, facilitates the employment of women (commerce and production), makes people more aware of the importance of natural and cultural assets, provides new recreational options for locals and widens the knowledge of the population on the world, hence promoting the acceptance of other people.

Of the negative factors which can be captured financially, the obvious profit-orientation of investments, the rise in prices (for at least the duration of the festival), the erosion of the 
natural and built environment, the overuse and faster erosion (decay in public services) of existing infrastructure, devaluation of real estate due to the overuse of the environment, sometimes the lack of goods at retailers, come to mind.

In addition, festivals induce a sharp increase in the number of crimes (theft and robbery), crowdedness and decay in the recreational opportunities of locals.

The above examples show that gastronomic festivals exert an influence on their own environment in numerous areas regardless of whether they are related to the specific factor or character.

\section{OBJECTIVES AND METHODS}

\section{Database and hypotheses}

Since in the course of my research I have not found a single publication that would have consolidated these events, I started my own search, which was mainly based on the works of Magyar Tourmix Kft. who are primarily engaged in processing data related to tourism. ${ }^{67} \mathrm{To}$ my surprise, they had more data and information than the official sources, KSH, Magyar Turizmus ZRt., or national organisations, Hungarian Festival Association and the Hungarian National Gastronomic Association.

The research conducted so far and the literature itself verified the fact - otherwise already recorded in Hungarian papers - that festivals have an ever greater importance, and have grown exponentially in the last one and a half decade. There are hundreds of festivals even in Hungary practically making them the megatrend of cultural tourism. (Sulyok and Sziva, 2009).

If we look closer, gastronomic festivals have a prominent place constituting about $30 \%$ of all festivals; their importance was pointed out in Kalkstein-Silkers, 2007. The study of Turizmus ZRT. conducted between early January 2009 and the end of February 2010 also concluded that, within festivals in Hungary, gastronomic events have had the largest number of visitors. Out of 741 persons in the survey, 30.8\% took part in gastronomic events. (Sulyok, 2010 In: Sándor, 2012).

Magyar Tourmix Kft. keeps a record of events in a breakdown of settlements, to my advantage, which was quite useful later, at the time of analysing the data. When the data were being sorted, the fact specified in many places immediately became visible - namely that the festival market has an automated nature, in that there are a large number of regional and local

\footnotetext{
${ }^{67} \mathrm{http}: / /$ www.programturizmus.hu/tdcategory-fesztival-esemeny-rendezveny-magyarorszag.html
} 
events attracting fewer visitors outside the realm of international and national festivals with a great number of guests and visitors (Erdős, 2004, In: Kundi, 2012).

Considering that, beyond their direct economic impacts, festivals might have a quite strong image-building role (Hunyadi at al., 2006.), which is, in my opinion, their most important role. When gathering data, as a first step I wanted to see the regional distribution (NUTS 1-23 ,) of festivals that constituted the foundation of future analyses.

The database developed by myself contains 213 specifically gastronomic events in 122 settlements with the exception of 2013. After looking at the table I found that, in Hungary, gastronomic events show a normal distribution from virtually all perspectives (number, venues, settlements) at the level of NUTS1 - that is, there is no significant difference in this between developed and less-developed areas of the country. However, there are considerable differences at county level. Not only in Budapest, where the difference can be attributed to its economic, cultural and political dominance, but also, for instance Veszprém, Borsod and Békés are considered the "great powers" of gastrofestivals, and the reason is not so simple as with the capital.

In the beginning of my study, this short table confirmed my conviction that many in Hungary know or at least "feel" the image-building role of festivals (Picard and Robinson, 2006), and its significance and effect in tourism and economy - competitiveness, capital attraction and profit generation (Harsányi, 1997, Enyedi, 2002).

Based on the above we could safely say that the impacts of gastronomic festivals on the local economy can be captured directly and with methodological tools. However, is this effect so trivial?

The literature (Jandala, 1992, Puczkó and Rátz, 2001), as well as my research, verify that in examining the effect of gastronomic festivals, dataa presenting the effect of tourism on economy in general are used as a starting point.

Among these, perhaps the most practical factor that can be captured at settlement level is the number of guest nights spent in individual settlements. The examination of their development and the implementation of gastronomic festivals could give an answer to our question.

On the basis of the above, I laid down the following hypotheses:

H1: There is positive correlation between gastronomic festivals and indicators measuring the performance of local tourism. 
H2: The effects of gastronomic festivals can be clearly seen in accommodation which was not primarily offered for simple touristic reasons, but which is regularly used for such purposes to satisfy an increased touristic demand.

\section{Tourism factors}

As a first step, data relating to the tourism industry and the settlement were gathered at county level, and then at settlement level. Data collection was based on the page of the KSH's official website representing local statistics.

In the course of processing the data, I was faced with the fact that, in a statistical sense, the most up-to-date and relatively reliable data are only from 2011, woth a limited pool of information on recent years in relation to festivals - and I often had to presume that the event had already existed in 2011. In the first steps, I had data relating to 102 variables, but many of these were not available for a large proportion of settlements or were irrelevant based on my first assumptions. Occasionally, the use of aggregates seemed more reasonable. After pruning the independent variables, the following were used:

- the area of the settlement $\left(\mathrm{km}^{2}\right)$,

- the number of permanent residents (persons),

- the number of hospitality places (places),

- number of beds at pensions (beds),

- number of guest nights at commercial accommodation (guest nights),

- number of guest nights spent by foreigners at commercial accommodation (guest nights),

- the number of beds at all commercial accommodation (beds),

- number of guest nights at pensions (guest nights),

- the number of foreigner guests at pensions (guests),

- the total number of hosts at other (until 2009 private) accommodation,

- the total number of beds at other (until 2009 private) accommodation,

- the number of foreigner guests at other (until 2009 private) accommodation,

- the number of guest nights spent by foreign guests at other (until 2009 private) accommodation,

- the number of guest nights at other (until 2009 private) accommodation,

- number of registered job-seekers

In selecting the above independent variables their logical and technical connection to the feasibility and implementation of gastronomic festivals was fundamental. The number of 
various types of accommodation, the number of hospitality units and changing types of guest night seemed adequate both in the analysis of the entire tourism industry and in our case. Selection by size of settlement seemed at first to be good, as it is general experience that larger settlements basically have better and more extensive infrastructural capabilities than smaller ones, and the "stress-bearing ability" of towns with larger capacities is also higher, meaning that they can better respond to rapidly changing needs arising in relation to festivals. Selection by population is important due to the number of visitors or crowdedness, since, as mentioned earler, an individual festival is not necessarily a destination asset; it does not encourage anyone to start a journey but is an alternative programme which may prompt potential visitors go for a trip. It is, therefore, important that we take into account the costs of travelling (travelling time, cost of means of transport...), or there is already a critical number of potential visitors in the area. It is not by chance that, by settlement, Budapest has the most events by far in the country. Finally, among the independent variables the number of jobseekers could give indications regarding the available free workforce and consumer numbers. However, since I would have to treat a vast amount of data even after narrowing them down, it seemed sensible to me to reduce the number of variables using factor analysis and create indicators that might give relevant answers to my hypotheses.

As a first step, all variables were compared to population numbers - to filter out distorting effects arising from the sheer size of the population.

After this, empirical analysis was performed using the IBM SPSS statistical software. The primary objective was to create indicators that might lead to conclusions on the effects of festivals. Since the demands which estivals generate do not appear evenly, but "abruptly" in the tourist industry of a region, their effect can be capture more easily rather in respect of "alternative infrastructure" (in my own definition this term covers material and service conditions that are not created for satisfying specific needs, but whose free capacities enable extended demand to be satisfied). As a result, I strove to create factors that reflect this. On the basis of preliminary analyses and the literature referred to above, the following indicators were chosen for factor analysis.

In addition to guest nights, the numbers of beds are also important parts of the analysis, since this is exactly what highlights basic touristic capacities - that is, how far tourism can be developed with minor increases in costs. In the absence of that, it would be easy to draw false conclusions in respect of actual capacity, encouraging unnecessary or excessive investment.

As a first step the analysis is performed by assuming one factor, based on the fact that $91.691 \%$ of the information content of original variables is explained by the linearly 
Bottyán, I.

independent group of variables created by factor analysis. After the inspection of the information content of certain factors and own values (eigenvalues) carrying this, the creation of the two factors is supported. Accordingly, further analyses were run assuming the existence of two factors.

In the matrix obtained in this wat and with items significantly weighted in terms of particular factors, the first factor was assigned to tourist traffic received by 'other accommodation', whilst the second was identified as tourist traffic received by 'commercial accommodation'.

This is an important result for me, as I can now differentiate in terms of traditional (commercial) and "alternative" (other) accommodation using these two factors, intensifying the regional impacts of festivals. I expect that their effect will be significant in the case of the latter factor.

Factors will now be referred to as follows: First factor: "tourism other accommodation", Second factor: "tourism commercial accommodation".

In order to verify or refuse my first hypothesis, perhaps the most often applied method of econometrics, namely the method of the smallest squares, was used (Sipos and Kehl, 2010). I also examined the correlation between the first factor (dependant variable) obtained primarily at multiple-day festivals (explaining variables) and my model was run on this. Differentiating in case of multiple-day festivals seemed necessary since it was assumed that multiple-day festivals have a larger effect on the most important tourism indicator available to me, guest nights. Accordingly, a multiple-day festival organised in a region or settlement will encourage the visitors to stay for more than one day. Difference was made between one-day and multiple-day festivals using variables " 0 " and "1" in cluster analysis within the database by assigning value " $1 "$ to multiple-day and value " 0 " to one-day festivals. A similar grouping was applied for the types of settlement, where "1" was assigned to settlements classified as town and "2" was applied to other settlements, making up the parameterisation of a total of 213 settlements.

\section{RESULTS}

\section{Analysis of the correlation between gastronomic festivals and indicators measuring the performance of local tourism}

When running the first model, the type of settlement, population and area control were represented as variables. The level of explanation which the table obtained at the first running of the model was not so high $(\mathrm{r} 2=0.163)$, but the assessment also shed some light on the fact 
that it is marginally significant $(\mathrm{F}=2.345 ; \mathrm{p}=0.052)$. That is, the model, even though it only explains $16.3 \%$ of the dispersion of the result variable, is relevant.

In the following I assessed whether all independent variables are needed in the model or their correlation leads to distortion in the result. On the basis of the VIF indicator (Variance Inflated Factor), the number of festivals and the population show a strong correlation with each other $(\mathrm{VIF}=21.339$ and $\mathrm{VIF}=22.741)$, meaning that it is recommended to remove either indication from the model. Further, owing to their low t-test value and high related significance value, the variables representing the type of settlement $(p=0.950)$ and the multiple day nature of festivals was removed $(\mathrm{p}=0.555)$.

The data obtained after rerunning the model showed that the explanatory power of the model is not very high $\left(\mathrm{r}^{2}=0.128\right)$, and not even significant $(\mathrm{F}=4.611, \mathrm{p}=0.014)$.

Even though it shows positive correlation $($ Beta $=0.151)$ between the number of festivals and a certain amount of tourism factors, but its significance level is too high $(\operatorname{sig}=0.278)$ hence the connection is not verified.

In the following a similar examination was made using the second tourism factor (tourism commercial accommodation). The explanatory power of the model is not very high $\left(\mathrm{r}^{2}=\right.$ 0.049), and not even marginally significant $(\mathrm{F}=0.613 ; \mathrm{p}=0.690)$.

On this basis the model could be abandoned, but the correlation of independent variables was examined to verify results.

Here, I obtained a similar correlation to that of the first factor - that is, the two variables are strongly correlated $($ VIF number of festivals $=21.339$; VIF population $=22.741)$; Hence I could narrow my model and run the analysis repeatedly - due to their exceedingly high empirical significance level, the variables representing the type of settlement $(p=0.667)$ and the multiple day nature of festivals $(p=0.506)$ - and then rerun the model.

The result is not significantly different from the first factor if the model is narrowed down in this way. Based on this, the model does not show significant $(F=0,871, p=0,424)$ explanatory power, hence it is irrelevant as a whole. Using the Beta version (Beta = 0.050), however, we can assume some positive connection between festivals and the second tourism factor, but the effect is quite weak and statistically not significant.

Overall, it was found that there is no detectable connection between gastronomic festivals and local tourism indicators. It is therefore likely that festivals, in the case of the factor containing commercial accommodation, do not represent a size that would lead to a significant connection. Otherwise, this is logical, since festivals essentially generate abrupt, 
rapid and simultaneous needs often exceeding local basic capacity, to be satisfied only by using the capacities provided by alternative infrastructure.

However, the factors used in the model are artificial, complex variables and bear the effect of numerous other factors that did not result in a significant and interpretable connection. Consequently, the first hypothesis must be totally rejected, and to show the effects of gastronomic festivals on direct tourism requires further examination. Chronological analyses might be practical in the future, although these would require the extension of the existing database.

In the continuation of the study, the distinguished conceptual indicator of tourism, the number of guest nights becomes the core of the analysis.

The effects of gastronomic festivals can be clearly seen in accommodation which was not primarily offered for simple touristic reasons, but which is regularly used for such purposes to satisfy an increased touristic demand

My second hypothesis is set to find answer for a previous statement, namely that the effect of gastronomic festivals can be explicitly measured in the alterative touristic infrastructure. To verify this, a new dependant variable was chosen to be included in the regressional model, which directly contains the number of domestic guest nights. Since my previous studies and research showed that festivals represent a self-contained destination value predominantly in domestic tourism, that is, their direct effect can be measured here.

On the basis of the study however this model has not shown a significant $(\mathrm{F}=1.607, \mathrm{p}=$ $0.167)$ explanatory power, and so there is no measurable difference in terms of commercial accommodation between one and multiple-day festivals. This could possibly be so due to the small weight which guest-nights generated by festisvals have in the volume of commercial accommodation.

The effects of gastronomic festivals can be clearly seen in accommodation which was not primarily offered for simple touristic reasons, but which is regularly used for such purposes to satisfy an increased touristic demandg if domestic 'other accommodation' is examined.

Here, it becomes obvious in creating the first model that there is a connection between multiple-day festivals and guest nights spent at other accommodation, as the model shows $(F=5.345, p=0.000)$. However, its explanatory power is not high $(0.229)$. Also, we can see that the connection between the multi-day nature of festivals and the domestic tourism received at other (non-commercial) accommodation is positive $($ Beta $=0.838)$. 


\section{SUMMARY AND CONCLUSIONS}

H1: There is a positive correlation between gastronomic festivals and indicators measuring local tourism.

\section{Not verified}

T1:Neither of the two touristic indicators created verified any existing or positive correlation with the number of festivals. Accordingly, further studies are needed aimed at filtering out the component that caused the lack of correlation between factors and festivals from the indicator group measuring local tourism.

H2: We can demonstrate difference between the impact "multiple-day" festivals and "oneday" events have on domestic guest nights.

\section{Partially verified}

T2:In this case by separating domestic accommodation into two parts, similarly to the two touristic factors created previously, it was established that gastronomic festivals only have a positive effect in relation to smaller 'other' accommodation.

Two regressions would be more favourable: commercial and 'other' guest nights

Overall, the greatest product of the study has been that a database was developed which summarises gastronomic events, contains statistical data which might support other studies or the running of new regressions relating to commercial and 'other' accommodation.

The study also pointed to the fact that capturing the effects of gastronomic festivals is not a simple task and requires further research in the literature and empirical research. To do this, however, a much more complex and a chronological set of data would be needed.

It is obvious to me that, beyond a basic tourism infrastructure, festivals rely on alternative solutions, and hence this could be one factor in, at least, the partial understanding of the economic multiplier and spillover effects. For this, however, I would need to find variables which allow me to come close to these effects. Moreover, mapping the relationship of gastronomic festivals and their relationship with agriculture - as well as a cluster analysis of settlements currently organising festivals are my priorities.

For further comparative analyses an examination of settlements without gastronomic festivals might be interesting.

\section{Acknowledgement}

I would like to express my gratitude to the Head of my PhD School in Pécs, Professor Dr. Attila Varga, who believed in my research and gave me this valuable opportunity. 
I am also most grateful to my consultant, Dr. Márta Bakucz, who has encouraged me so strongly over these past three years and dissuaded me from abandoning the course.

I would finally offer my grateful thanks to my classmate, András Bozóti, with whom I could always profitably discuss my research.

\section{REFERENCES}

Bayrak, G. Ö. (2011.). Festival motivators and consequences: a case of Efes Pilsen Blues Festival, Turkey, Anatolia. An International Journal of Tourism and Hospitality Research Vol. 22, No. 3, November 2011.378-389

Bayrak, G. Ö., Çulha, O. (2009.). Satisfaction and Loyalty of Festival Visitors, Anatolia. An International Journal of tourism and Hospitality Research Volume 20. Number 2. pp, 359373, 2009.

Bolgár, B. (2011). A síturizmus gazdasági hatásainak vizsgálata Kisbányahavas esettanulmány (Assessment of the economic impacts of ski tourism Kisbányahavas case study). Debreceni Egyetem, Tájvédelmi és Környezetföldrajzi Tanszék

Bonilla, J. M. L., Bonilla, L. M. L., and Altamira, B. S. (2010). Designated Public Festivals of Interest to Tourists. European Planning Studies. Vol. 18, No. 3, March 2010.

Csapó, J., Matesz, K. (2007). A kulturális turizmus jelentősége és szerepe napjaink

idegenforgalmában (The significance of cultural tourism in the tourism of our days). Földrajzi Értesitő 2007. LVI. évf. 3-4. füzet, 291-301.

Duarte, A. and Yi, L. (2011). Visitor Centers, Collaboration, and the Role of Local Food and

Beverage as Regional Tourism Development Tools: The Case of the Blackwood River Valley in Western Australia. Journal of Hospitality \& Tourism Research, November 2012; Vol. 36, 4: pp. 517-536.

Erdős, A. (2004). A jelenkori Dionüszosz ünnepek - Az esemény turizmus helyzete egy kvantitatív kutatás szemszögéböl (Modern day Dionysus festivities - The situation of events tourism from the aspect of quantitative research). Turizmus Bulletin. 8(1) pp. 3340 .

Saaymana, M. and Rossouw, R. (2010). The Cape Town International Jazz Festival: More than just jazz. Development Southern Africa Vol. 27, No. 2: pp. 255-272.

Hall, M. C. (2003). Food Tourism Around the World. Elsevier Publishing House.

Harris, R. and Howard, J. (1996). Dictionary of travel, tourism and hospitality terms. Hospitality Press, Australia.

Hertanu, A.and Boitor, B. (2012). S.T.E.P. Analysis on event tourism. Bulletin of the Transylvania University of Braşov. Vol. 5 (54) No. 2 - 2012 Series V: Economic Sciences.

Hjalager, A. and Richards, G. (2004). Tourism and Gastronomy. Taylor \& Francis Publishing House.

Hunyadi, Zs., Inkei, P., Szabó, J. Z. (2006). Fesztivál-világ (Festival world).

Budapest NKA research 3. Budapest 2006.

Indra, D. (2009). A Balaton Sound és a VOLT Fesztivál gazdasági hatásvizsgálata (Economic impact assessment of Balaton Sound and VOLT Festival). Turizmus Bulletin, Vol. XIII, 3. sz. pp.: 31-35.

Jandala, Cs. (1992). A turizmus közgazdasági elemzésének módszere (The method of analyzing tourism from the aspect of economy). Kereskedelmi és Idegenforgalmi Továbbképző Kft., Budapest.

Kalkstein-Silkes, C.A., Lehto, X. Y., Cai, L.A. (2007). Food and food related elements of festival brochures in rural Indiana: A content analysis. 2007 Annual International CHRIE Conference \& Exposition.

Kivela, J. and Crotts, J. C. (2006). Tourism and Gastronomy: Gastronomy's Influence on How 
Tourists Experience a Destination. Journal of Hospitality \& Tourism Research. August 2006 Vol. 30 no. 3 pp. 354-377.

Kivela, J. and Crotts, J. C. (2009). Understanding Travellers' Experiences of Gastronomy Through Etymology and Narration. Journal of Hospitality \& Tourism Research, May 2009; Vol. 33, 2: pp. 161-192.

Kundi, V. (2012). Fesztiválok gazdasági hatásmérésére alkalmazott nemzetközi és hazai modellek bemutatása. (Introduction of international and national models applied for measuring the economic impact of festivals). Tér és Társadalom, Vol. 26, No. 4, 2012.

Kundi, V. (2012). Fesztiválok városokra gyakorolt gazdasági- és társadalmi-kulturális hatásainak elemzése a győri Magyar Táncfesztivál és a Miskolci Operafesztivál példáján keresztül (Analysis of the economic and socio-cultural impacts of festivals on towns using the Hungarian Dance Festival in Györ and the Opera Festival in Miskolc as examples). Draft dissertation, István Széchenyi Regional and Economics Doctoral School, Györ.

Lakićević, M., Žarevac, M., and Pantić N. (2010). Gastronomic Festivals in Rural Regions of Serbia. Megatrend Review, 2012 Vol. 9 (1): pp. 73-82.

Lee, I., and Arcodia, C. (2011). The Role of Regional Food Festivals for Destination Branding. International Journal of Tourism Resarch 13, pp. 355-367.

Lengyel, M. (2004). A turizmus általános elmélete (The General Theory of Tourism). Kereskedelmi és Idegenforgalmi Továbbképző, Budapest.

Michalkó, G. (2004). A turizmus elmélet alapjai (Fundamentals of tourism theory). Kodolányi János University, Székesfehérvár.

Nemes, A., (2008.). A Turizmus gazdasági jelentősége nemzeti és regionális szinten (The economic significance of tourism at a national and regional level). Társadalom és Gazdaság 30 (2008) 2, 285-296.

Ottenbacher, M. C. and Harrington, R. J. (2011). A Case Study of a Culinary Tourism Campaign in Germany. Journal of Hospitality \& Tourism Research. February, 2013 37: 3-28. First published on July 18, 2011.

Picard, D. and Robinson, M. (2006). Festivals, Tourism and Social Change: Remaking Worlds. Clevedon, Channel View.

Popescu, R. I., and Corbos, R. A. (2012). The Role of Festivals and Cultural Events in the Strategic Development of Cities. Recommendations for Urban Areas in Romania. Informatica Economică, Vol. 16, no. 4/2012.

Puczkó, L., Rátz T. (2001). A turizmus hatásai (Impacts of tourism). Aula Kiadó, Budapest.

Puczkó, L. (1999). Turizmus és környezet. Turizmus vagy környezet (Tourism and environment. Tourism or environment?). $\mathrm{PhD}$ dissertation, Budapest Corvinus University.

Rappai, G. and Pintér, J. (2007). Statisztika (Statistics). University of Pécs, Pécs

Rátz, T. és Pattermann L. (2004). A karácsony, mint turisztikai attrakció (Christmas as a touristic attraction). Turizmus Bulletin. http://neta.itthon.hu/site/upload/mtrt/Turizmus_Bulletin/bulletin200403/18_karacsony.p df

Rátz, T. (1999). A turizmus társadalmi-kulturális hatásai (Socio- cultural impacts of the tourism). PhD dissertation, Budapest Corvinus University of Economics, Budapest.

Renko, S. (2010). Food in the Function of Rural Development in the Context of Tourism Industry http://www.un.org/esa/agenda21/natlinfo/countr/croatia/ruralDevelopment.pdf

Richards, G. (2007). Cultural Tourism: Global And Local Perspectives Taylor\& Francis

Ruxandra-Irina Popescu, R. I., Răzvan-Andrei CORBOŞ (2012.) The Role of Festivals and Cultural Events in the Strategic Development of Cities. Recommendations for Urban Areas in Romania Informatica Economică Vol. 16, no. 4/2012 
Saayman, M. \& Rossouw, R. (2010.). The Cape Town International Jazz Festival: More than just jazz. Development Southern Africa Volume 27, Issue 2. 2010.

Sajtos, L. and Mitev, A. (2006). SPSS kutatási és adatelemzési kézikönyv (Manual of SPSS research and data analysis). Alinea Kiadó, Budapest. pp. 245-282.

Sándor, D. (2012). A gasztronómia szerepe Magyarország idegenforgalmi földrajzában (The role of gastronomy in the touristic geography of Hungary). PhD essay, University of Pécs, Doctoral School of Earth Sciences.

Savarin, J.A.B. (1825). La Physiologie du Goût (The physiology of taste)

Seongseop, S. K., Park, J.Y, and Lee, J. (2010). Predicted Economic Impact analysis of a Mega-Convention Using Multiplier effects. Journal of Convention \& Event Tourism, 2010. 11. pp. 42-61.

Sipos, B. and Kehl, D. (2010). Regressziós modellek becslése és tesztelése Excel-parancsfájl segítségével (szoftverismertetés) (Estimation and testing of regressional models using Excel command file (software teaching)). Statisztikai Szemle, (2010) Vol. 88, no. 7-8.

Smith, M. (2009). Fesztiválok és turizmus: lehetőségek és konfliktusok (Festivals and tourism: opportunities and conflict). Turizmus Bulletin, Vol. XIII., No. 3. Budapest, pp. 23-27.

Steliana, C. and Molnar, E. (2009). Measures and inititatives adopted to manage and develop tourism activity in the EU member state. Annals of the University of Oradea Economic Science.

Sulyok, J., Sziva, I. (2009). A fesztiválturizmus nemzetközi és hazai tendenciái (International and national tendencies of festival tourism). Turizmus Bulletin, Vol. XIII, No. 3. Budapest, pp. 3-12.

Székelyi, M., Barna, I. (2008). Túlélőkészlet az SPSS-hez. Többváltozós elemzési technikákról társadalomkutatók számára (Survival kit to SPSS. On multiple variable analysis techniques for researchers of social sciences). Typotex Elektronikus Kiadó Kft.

Szerb, L. (2010). A magyar mikro, kis- és középvállalatok versenyképességének mérése és vizsgálata (Measuring and assessing the competitiveness of Hungarian micro, small and medium-sized enterprises). Vezetéstudomány 41. December 2010. pp. 20-35.

Sziva, I. (2012). Turisztikai desztinációk klasztertérképei (Ki a felelős a desztinációk versenyképességéért?) [The "cluster-map" oftourist destinations (Who is responsible for the competitiveness of destinations?)]. Tér és Társadalom, Vol. 26, No. 1.

Vrettos, A. (2009). About the economy impact studies of arts festivals. Economia della Cultura 3/2009. pp. 341-350.

\section{Web sources}

http://www.programturizmus.hu/tdestination-gasztronomiai-fesztivalok.html

http://www.eturizmus.pte.hu/szakmai-

anyagok/Turisztikai\%20term\%C3\%A9ktervez\%C3\%A9s\%20\%C3\%A9s\%20fejleszt\%C3

$\%$ A9s/book.html\#d6e2237

http://www.ksh.hu/teruleti_4

http://www.mngsz.com/programajanlo/

http://www.kolbaszfesztival.eu/52/sajtofigyelo

http://csabaikolbaszfesztival.hu/?module $=$ news\&op=list\&indexp=true

http://www.programturizmus.hu/tdestination-gasztronomiai-fesztivalok.html 